\title{
EFFECT OF PHYTATE AND IRON-BINDING PHENOLICS ON THE CONTENT AND AVAILABILITY OF IRON AND ZINC IN MICRONUTRIENTS FORTIFIED CEREAL FLOURS
}

Elifatio Towo* ${ }^{1,2}$, Celestin Mgoba ${ }^{1}$, Godwin D. Ndossi ${ }^{1}$ and Sabas Kimboka ${ }^{1}$

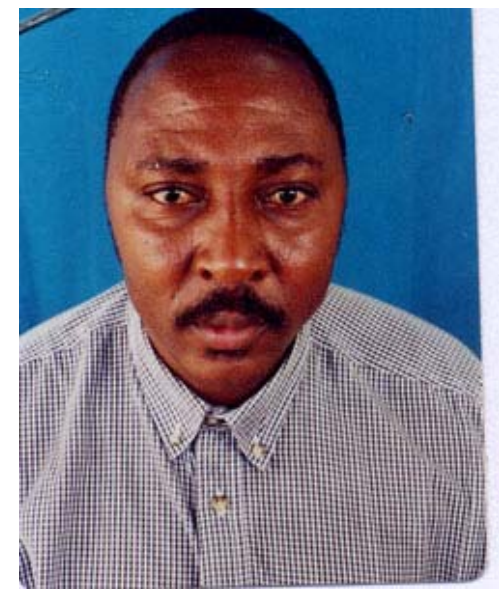

Elifatio Towo

${ }^{1}$ Tanzania Food and Nutrition Centre, Ocean Road No 22, Box 977, Dar es Salaam, Tanzania.,

${ }^{2}$ Department of Chemistry, Bioscience/Food Science, Chalmers University of Technology, Box 5401, SE 402 29, Gothenburg, Sweden

*Corresponding author:

Tanzania Food and Nutrition Centre, Ocean Road No 22, Box 977, Dar es Salaam, Tanzania E-mail: eetowo@hotmail.com 


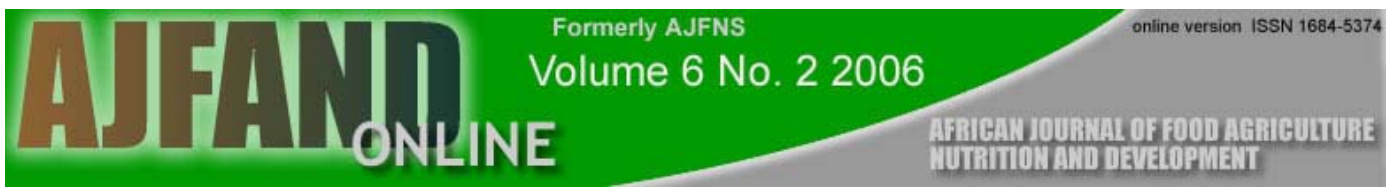

\section{ABSTRACT}

Iron deficiency anaemia is highly prevalent in Tanzania-affecting predominantly children and women. Fortification of cereal flour with micro-nutrients is being carried out as a strategy for combating micro-nutrient deficiencies. Four different cereal flours were fortified with micro-nutrients and evaluated for total and bioavailable iron and zinc, iron binding polyphenolics, phytate content and ascorbic acid. The extractable total phenolics ranged from 1.3 (maize) to 19.4 (redsorghum) $\mathrm{mg}$ catechin equivalent $(\mathrm{CE}) \mathrm{g}^{-1}$. Catechols ranged from 1.1 (maize) to

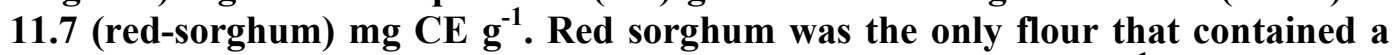
high amount of galloyls (4.0 $\mathrm{mg}$ tannic acid equivalent (TAE) $\mathrm{g}^{-1}$ ). All samples contained high amounts of phytate $\left(10.7 \pm 1.0 \mu \mathrm{mol} \mathrm{g}^{-1}\right)$. The average total iron was $42.26 \pm 10.26 \mathrm{mg} \mathrm{kg}^{-1}$ in the unfortified and $52.67 \pm 10.19 \mathrm{mg} \mathrm{kg}^{-1}$ in the fortified cereal flours and the average in vitro available iron was $1.03 \pm 0.30 \mathrm{mg} \mathrm{kg}^{-}$ 1 and $1.65 \pm 0.31 \mathrm{mg} \mathrm{kg}^{-1}$ respectively. The average zinc content was $21.4 \pm 3.10 \mathrm{mg}$ $\mathrm{kg}^{-1}$ and $25.9 \pm 2.84 \mathrm{mg} \mathrm{kg}^{-1}$ in the unfortified and fortified flours respectively and the average available zinc was $0.30 \pm 0.12 \mathrm{mg} \mathrm{kg}^{-1}$ and $0.53 \pm 0.16 \mathrm{mg} \mathrm{kg}^{-1}$ respectively. No ascorbic acid was detected in any of the unfortified flour, and a little amount was detected in the fortified red sorghum $\left(4.5 \mathrm{mg} \mathrm{kg}^{-1}\right)$, compared to the white sorghum $\left(11.1 \mathrm{mg} \mathrm{kg}^{-1}\right)$, finger millet $\left(15.8 \mathrm{mg} \mathrm{kg}^{-1}\right)$ and maize $(29.6 \mathrm{mg}$ $\left.\mathrm{kg}^{-1}\right)$. There was no significant increase of in vitro available iron $\left(0.02 \mathrm{mg} \mathrm{kg}^{-1}\right)$ and zinc $\left(0.06 \mathrm{mg} \mathrm{kg}^{-1}\right)$ availability in the red sorghum. The in vitro available iron increased by $3.8 \%$ in finger millet, by $9.2 \%$ in white sorghum, and by $10.1 \%$ in maize four-compared to respective total iron content as a result of fortification. In vitro available zinc increased by $7.9 \%$ in finger millet, by $4.8 \%$ in white sorghum and by $5.9 \%$ in maize flours, compared to respective total zinc content as a result of fortification. It was concluded that other dietary modification strategies that are being carried out for the improvement of native iron and zinc bioavailability (processing for decreasing inhibitory factors, consumption of fruits and green leafy vegetables for enhancing absorption and nutrition education) should accompany fortification of flours with micro-nutrients. The red sorghum is not recommended as a good vehicle for food fortification with iron and zinc.

Key Words: Micronutrient, fortification, iron, zinc, polyphenols, phytate, cereal flour

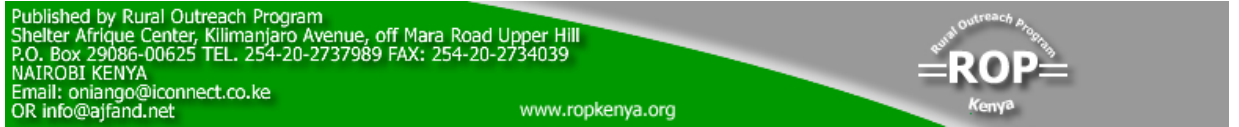


French

EFFET DU PHYTATE ET DES PHÉNOLIQUES SIDÉROPEXIQUES SUR LA TENEUR ET LA DISPONIBILITÉ DU FER ET DU ZINC DANS LES FARINES DE CÉRÉALES VITAMINÉES PAR DES MICRONUTRIMENTS

\section{RÉSUMÉ}

L'anémie caractérisée par une carence de fer est fortement répandue en Tanzanieles personnes les plus affectées étant les femmes et les enfants. La vitaminisation des farines de céréale par des micronutriments est réalisée en tant que stratégie de lutte contre les carences en micronutriments. Quatre différentes farines de céréale ont été vitaminées grâce à des micronutriments. Une évaluation de la teneur et l'assimilabilité du fer et du zinc, du fer liant les polyphénoliques, du phytate et de l'acide ascorbique a été faite. Le total des phénoliques extractibles oscillait entre $1,3 \mathrm{mg}$ (maïs) et 19,4 mg (sorgho rouge) de catéchine (CE) $\mathrm{g}^{-1}$. Les catéchols variaient entre 1,1 mg (maïs) et $11,7 \mathrm{mg}$ (sorgho rouge) $\mathrm{CE} \mathrm{g}^{-1}$. Le sorgho rouge était la seule farine qui contenait une quantité élevée de galloyls (équivalant à 4,0 mg d'acide tannique (TAE) $g^{-1}$ ). Tous les échantillons contenaient de grandes quantités de phytate $\left(10,7 \pm 1,0 \mu \mathrm{mol} \mathrm{g}{ }^{-1}\right)$. La moyenne totale du fer était de 42,26 $\pm 10,26 \mathrm{mg} \mathrm{kg}^{-1}$ dans les échantillons non vitaminés et de 52,67 $\pm 10,19 \mathrm{mg} \mathrm{kg}^{-1}$ dans les farines de céréales vitaminées et l'on constatait une moyenne de fer biodisponible in vitro de respectivement $1,03 \pm 0,30 \mathrm{mg} \mathrm{kg}^{-1}$ et $1,65 \pm 0,31 \mathrm{mg} \mathrm{kg}^{-1}$. La teneur moyenne en zinc était respectivement $21,4 \pm 3,10 \mathrm{mg} \mathrm{kg}^{-1}$ et $25,9 \pm 2,84 \mathrm{mg} \mathrm{kg}^{-1}$ dans les farines non vitaminées et vitaminées et la moyenne du zinc biodisponible était respectivement $0,30 \pm 0,12 \mathrm{mg} \mathrm{kg}^{-1}$ et $0,53 \pm 0,16 \mathrm{mg} \mathrm{kg}^{-1}$. L'acide non ascorbique a été détecté dans toutes les farines non vitaminées et une petite quantité a été trouvée dans le sorgho rouge vitaminé $\left(4,5 \mathrm{mg} \mathrm{kg}^{-1}\right)$, en comparaison au sorgho blanc $\left(11,1 \mathrm{mg} \mathrm{kg}^{-1}\right)$, au millet rouge $\left(15,8 \mathrm{mg} \mathrm{kg}^{-1}\right)$ et au maïs $\left(29,6 \mathrm{mg} \mathrm{kg}^{-1}\right)$. Il n'y avait pas d'augmentation significative dans la disponibilité du fer in vitro $\left(0,02 \mathrm{mg} \mathrm{kg}^{-1}\right)$ et du zinc $\left(0,06 \mathrm{mg} \mathrm{kg}^{-}\right.$ 1) dans le sorgho rouge. Le fer assimilable in vitro a augmenté de 3,8\% dans le millet rouge, de 9,2\% dans le sorgho blanc, et de 10,1\% dans le mä̈s -en comparaison à la quantité totale de fer à la suite de la vitaminisation. Le zinc biodisponible in vitro a augmenté de $7,9 \%$ pour le millet rouge, de 4,8\% pour le sorgho blanc et de 5,9\% dans les farines de maïs, en comparaison à la teneur totale respective en zinc suite à la vitaminisation. Il a été conclu que les autres stratégies de modification diététiques qui sont réalisées en vue de l'amélioration du fer natif et de la biodisponibilité du zinc (traitement pour diminuer les facteurs inhibiteurs, consommation de fruits et légumes à feuilles alimentaires en vue de l'amélioration de l'assimilabilité et l'éducation alimentaire) doivent accompagner la vitaminisation des farines avec des micronutriments. Le sorgho rouge n'est pas recommandé en tant que bon vecteur de la vitaminisation des aliments avec le fer et le zinc.

Mots clés : Micronutriment, vitaminisation, fer, zinc, polyphénoles, phytate, farine de céréale

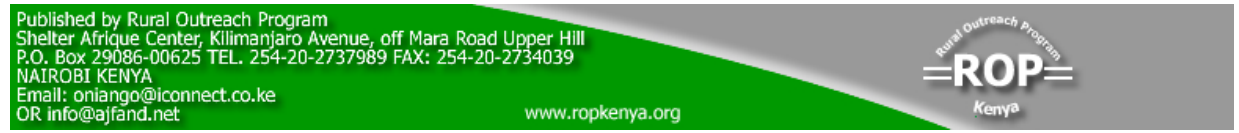




\section{INTRODUCTION}

Iron deficiency anaemia (IDA) is a world-wide problem affecting about 3.5-5.0 billion people and a much large number has iron deficiency without anaemia [1]. IDA is highly prevalent in Tanzania affecting predominantly children and women of childbearing age [2]. Anaemia is a late manifestation of iron deficiency and the main cause of iron deficiency is probably inadequate dietary intake of iron due to low iron bioavailability. Three factors usually determine the amount of iron absorbed from the diet. These are; the amount of iron ingested, its availability for absorption in the body, and the iron status of the individual. The first two factors are the major dietary determinants of iron bioavailability for absorption and can be controlled by dietary measures. Fortification of cereal flour with iron and other micronutrients are among strategies used for controlling iron deficiency [3].

Fortification of cereal flours with micronutrients is being pursued as one of the strategies for combating iron, zinc and other micronutrient deficiencies in Tanzania. Predetermined weight of premixes (in sachets) containing iron (in the form of ferrous fumarate) and zinc (zinc oxide) are used to fortify the flour, at the milling premises immediately after milling cereal grains into flour. Other micronutrients (fortificants) that are included in the premixes are calcium (calcium carbonate), vitamin $\mathrm{A}$ (palmitate), vitamin $\mathrm{B}_{1}$ (thiamin hydrochloride), vitamin $\mathrm{B}_{2}$ (riboflavin), vitamin $\mathrm{B}_{12}$ (cobalamin), vitamin $\mathrm{B}_{3}$ (niacinamide), folic acid and ascorbic acid. Cereal flours are known to contain phytate and polyphenolic compounds at varying concentration that might interfere with in vitro availability of iron, zinc and other micronutrients $[4,5,6$, 7]. Bioavailability of most fortificant iron (like ferrous fumarate) has been shown to be affected adversely by the inhibitory compounds of phytate and polyphenols [3]. Addition of calcium and/or zinc has also been shown to impair iron absorption, but inconsistent results are available on their interactions [7, 8, 9]. On the other hand, ascorbic and organic acids have been shown to improve the in vitro available iron, whereas ascorbic acid is known to be adversely destroyed by food processing and handling procedures $[6,10,11]$. Vitamin $A$ and $\beta$ carotene have also been shown to have a positive influence on iron absorption - though the topic is still under debate [12, $13,14,15,16]$.

In Tanzania, cereals used as the main meal differ from one area to another, ranging from high-tannin cereals like red-sorghum to low tannin cereals like maize. However, they all contain appreciable high amounts of phytate compounds [4, 5]. The iron content and its in vitro iron availability for absorption in different cereal flour fortified with micronutrients (under rural settings in Tanzania), have not being studied. This work was aimed at studying the feasibility of flour fortification with micro-nutrients to determine the iron and zinc contents - and evaluate their in vitro availability in different cereal flour fortified with micro-nutrients - and the effect of native inhibitory

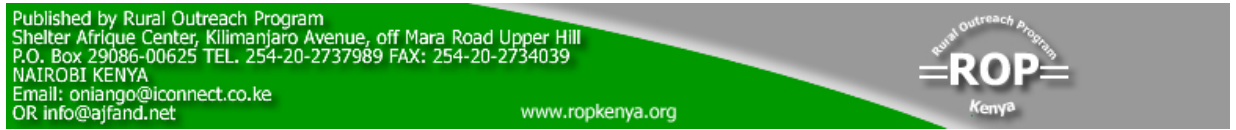




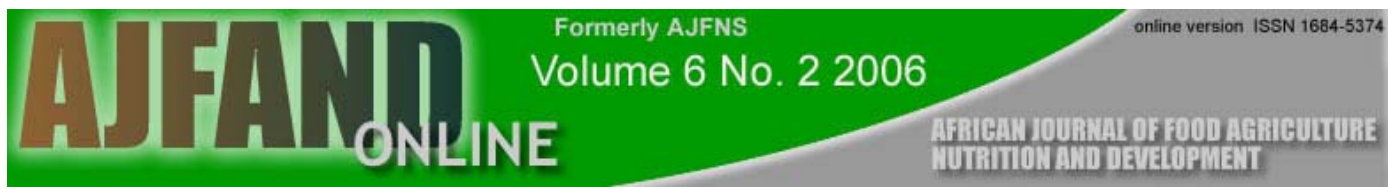

compounds of phytate and polyphenolics on the in vitro available iron and zinc bioavailability from fortified and unfortified samples.

\section{METHODS}

\section{Food samples and Fortification}

Cereal flours from maize, finger millet and white and high-tannin red sorghum fortified with micronutrients was used in the study. The cereals were collected from local markets in Dodoma (where red sorghum (udo) is readily cultivated and consumed) and Iringa (among the big maize producing area) regions in Tanzania, by random sampling procedure. The grains were milled into flour by hammer mills in Iringa-where a Pilot Fortification Project is being carried out in 26 villages. Fortification of cereal flours with iron and other fortificants was done right at the milling premises immediately after milling using a hand-operated batch mixer. The fortificants were obtained from International Health Food Association, Arusha Tanzania, which has its headquarter in Australia. The fortificants and levels of fortification are illustrated in Table 1. Duplicate samples of fine fortified cereal flour were analyzed for various factors.

\section{Analytical Methods}

\section{Determination of ascorbic acids}

Concentration of ascorbic acid was determined by high performance liquid chromatography (HPLC) [17]. A 0.5 g samples was extracted for $1 \mathrm{~h}$ with $9.0 \mathrm{ml}$ of

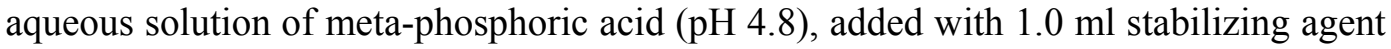
(Dithio-DL-threitol) in an ultrasonic water bath shaker. After extraction $1.0 \mathrm{ml}$ was centrifuged at 10,000 X g for 5 min and then the concentration determined by HPLC, using ascorbic acid as a standard.

\section{Determination of total and iron binding phenolic compounds}

The amounts of total phenolic compounds were determined by the Prussian blue method using acidified methanol $(1 \% \mathrm{HCl})$ as extraction solvent $[4,5,18]$. The ironbinding polyphenolic (catechols and galloyls) groups were determined by the modified ferric ammonium sulphate (FAS), using $50 \%$ dimethyl-formamide in acetate buffer $(\mathrm{pH} 4.4)$ as extraction solvent $[4,5,19]$. The extraction and determination procedures are as described earlier $[4,5,6]$. Results for total polyphenols and catechol are expressed in $\mathrm{mg} \mathrm{g}^{-1}$ catechin equivalents (CE) and galloyls in $\mathrm{mg} \mathrm{g}^{-1}$ tannic acid equivalents (TAE) all on dry weight basis.

\section{Determination of phytate content}

A $0.5 \mathrm{~g}$ sample of flour was extracted with $10 \mathrm{ml} 0.5 \mathrm{M} \mathrm{HCl}$ during stirring for $3 \mathrm{~h}$, followed by centrifugation at $2100 \times g$ for $10 \mathrm{~min}$ and filtration. The clear supernatant was analyzed for total phytate content with high performance ion chromatography (HPIC), as described by Carlsson et al., [20]. The HPIC was coupled with UV detection of post column reaction with $\mathrm{Fe}\left(\mathrm{NO}_{3}\right)_{3}$ at $290 \mathrm{~nm}$. An isocratic elution with $\mathrm{HCl}(0.8 \mathrm{M})$ was used with a retention time of 6 minutes per sample.

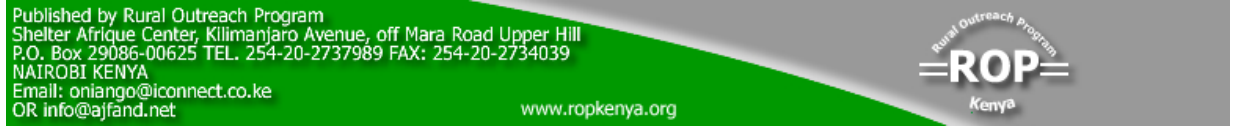




\section{Determination of mineral content and in vitro iron and zinc bioavailability}

The total iron and zinc were determined by wet acid digestion of the sample $(0.3 \mathrm{~g})$ in a microwave, using concentrated acid of hydrochloric $(0.15 \mathrm{ml})$ and nitric $(0.75 \mathrm{ml})$, followed by cooling and dilution. The concentration of iron and zinc were quantified according to the procedure by Fredrikson et al., [21]. The in vitro available iron was quantified by determining iron solubility at physiological conditions, by digestion with pepsin and pancreatin enzymes according to the method described by Svanberg et al., with some minor modifications and quantified by HPIC [4, 21, 22]. Zinc bioavailability was determined by HPIC after digestions of the flour, using pepsin and pancreatin enzymes simulating gastric and intestinal fluid [21, 23, 24]. The HPIC was coupled with UV-VIS detection of post column reaction with 4-(2-pyridylazo) resorcinol (PAR) at $500 \mathrm{~nm}$.

\section{Statistical analysis}

Differences in mean values were tested with analysis of variance (ANOVA) using SYSTAT (SYSTAT Inc, Evanston, US), and significant levels were obtained with Tukey's HSD multiple range test [32].

\section{RESULTS}

\section{Polyphenolics and phytate}

The extractable phenolic content in the analysed cereal flours varied widely (Table II). Total phenolics ranged from 1.3 to $19.4 \mathrm{mg}$ catechin equivalent (CE) $\mathrm{g}^{-1}$. The iron binding phenolic groups of catechols ranged from 1.1 to 11.7 catechin equivalent (CE) $\mathrm{g}^{-1}$, and galloyls ranged from 0.3 to 4.0 tannic acid equivalent (TAE) $\mathrm{g}^{-1}$. The red sorghum (udo) contained the highest amount of all types of extractable phenolics. White sorghum contained the least amount of extractable total phenolics, maize contained the least amount of extractable catechols, and finger millet contained the least amount of extractable galloyls. The extractable galloyl compounds were minimal in all grains $\left(<0.5\right.$ tannic acid equivalent (TAE) $\left.\mathrm{g}^{-1}\right)$, but the $u d o$ contained an appreciably high amount of these compounds (4.0 tannic acid equivalent (TAE) $\mathrm{g}^{-1}$ ). The phytate compound ranged from 9.6 to $12 \mu \mathrm{mol} \mathrm{g}^{-1}$, with red sorghum containing the least amount, and white sorghum the largest amount of extractable phytate compounds (Table II).

\section{Ascorbic acid}

Ascorbic acid was only obtained in the fortified cereal flour samples. The amount of ascorbic acid ranged from 4.5 to $29.6 \mathrm{mg} \mathrm{kg}^{-1}$, red sorghum contained the minimal, whereas maize contained the highest amount (Table III).

\section{Total and in vitro iron content}

Total iron in the unfortified cereal flours ranged from 35.1 to $51.1 \mathrm{mg} \mathrm{kg}^{-1}$, and that in the fortified flours ranged from 43.2 to $62.2 \mathrm{mg} \mathrm{kg}^{-1}$ (Table III). Total iron was significantly $(\mathrm{p}<0.05)$ higher in the fortified cereal flours compared to unfortified flours. The difference in total iron between fortified and unfortified cereal flours ranged




from 8.5 to $11.6 \mathrm{mg} \mathrm{kg}^{-1}$. The in vitro available iron in the unfortified cereal flours ranged from 0.42 to $1.79 \mathrm{mg} \mathrm{kg}^{-1}$, and that in the fortified one ranged from 1.41 to 1.81 $\mathrm{mg} \mathrm{kg}^{-1}$. The increase on in vitro available iron as a result of fortification of cereal flours was $0.02 \mathrm{mg} \mathrm{kg}^{-1}$ in red sorghum, $0.42 \mathrm{mg} \mathrm{kg}^{-1}$ in finger millet, $0.86 \mathrm{mg} \mathrm{kg}^{-1}$ in maize, and $0.97 \mathrm{mg} \mathrm{kg}^{-1}$ in white sorghum.

\section{Total and in vitro zinc content}

Total zinc in the unfortified cereal flours ranged from 16.9 to $23.7 \mathrm{mg} \mathrm{kg}^{-1}$, and that in the fortified flours ranged from 21.8 to $27.9 \mathrm{mg} \mathrm{kg}^{-1}$ (Table III). Total zinc was significantly high in the fortified cereal flours compared to unfortified flours. The difference in total zinc between fortified and unfortified cereal flours ranged from 4.1 to $4.9 \mathrm{mg} \mathrm{kg}^{-1}$. The in vitro available zinc in the unfortified cereal flours ranged from 0.20 to $0.46 \mathrm{mg} \mathrm{kg}^{-1}$, and that in the fortified flour ranged from 0.40 to $0.71 \mathrm{mg} \mathrm{kg}^{-1}$. The increase on in vitro available zinc as a result of fortification of cereal flours was $0.06 \mathrm{mg} \mathrm{kg}^{-1}$ in red sorghum, $0.39 \mathrm{mg} \mathrm{kg}^{-1}$ in finger millet, $0.25 \mathrm{mg} \mathrm{kg}^{-1}$ in maize and $0.20 \mathrm{mg} \mathrm{kg}^{-1}$ in white sorghum.

\section{DISCUSSION}

\section{Extractable polyphenolic and phytate content}

The amount of extractable polyphenolic compounds observed in the analysed cereal flour is within the range reported earlier, and the amount of phytate content reported in this study is also within the range reported elsewhere $[4,5,26]$. High content of polyphenolics and phytate compounds have been shown to adversely affect the absorption of native minerals like iron and zinc in cereal and legume foods $[19,22,26$, 27]. Food processing methods like germination and fermentation - that reduced these compounds to extremely lower levels - have been shown to have an increased effect on bioavailability of iron and zinc $[9,28]$.

Ascorbic acid content recovered in the fortified flours differ from each other, with recovery ranging from 4.5 (in red sorghum) to 29.6 (in maize) $\mathrm{mg}$ per $\mathrm{kg}$ compared to the added amount of $40 \mathrm{mg}$ per $\mathrm{kg}$ of flour. Ascorbic acid could have been degraded during handling and storage of the fortificant sachets [25]. Moreover, even the remaining ascorbic acid will disappear during post-fortification treatments like cooking of the flour into porridge, as it is highly unstable during heat processing, handling and storage [11].

\section{Total iron and in vitro available iron}

The bioavailability of the fortificant iron added to a food is determined by several factors; the form of iron fortificant used, the amount of added iron, the iron status of the individual, and the presence of other dietary constituents that either enhance or inhibit bioavailability. In this study the type of fortificant iron used was iron fumarate at a concentration of $15 \mathrm{mg} \mathrm{kg}^{-1}$, which indicates a recovery rate ranging from 57-77 per cent. Low and inconsistent recovery might have been due to un-inconsistence addition of iron to the flours and loss during storage of the pre-mix. Minerals such as copper,

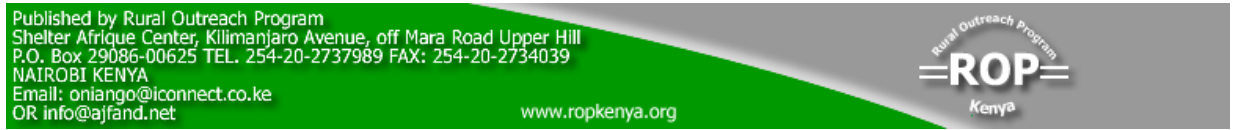


iron and zinc have been shown to be affected by moisture and can react with other food compounds during the storage of flour or pre-mix, and could have contributed in lowering of recovery of the added iron and zinc [33]. The in vitro available iron in the cereals varied considerably. There was no significant increase of in vitro available iron in red sorghum $(u d o)$ as a result of fortification. However, the in vitro available iron increased by $0.42 \mathrm{mg} \mathrm{kg}^{-1}$ in finger millet, $0.97 \mathrm{mg} \mathrm{kg}^{-1}$ in white sorghum and $0.86 \mathrm{mg}$ $\mathrm{kg}^{-1}$ in maize flour, as a result of fortification. These inconsistencies on the in vitro iron availability might have been caused by the presence of inhibitory compounds at a varying level in the cereal flours. The red sorghum used in this study contained an appreciably high amount of iron binding phenolic compounds (galloyls and catechols) that has been shown to adversely affect iron bioavailability $[4,19]$. In vitro vailability of iron fumarate used in food fortification have also been shown to be affected negatively by food inhibitors [13]. This might account for the low in vitro available iron in red sorghum as a result of fortification compared to the other cereals analyzed. Phytate compounds may have also accounted for the low iron bioavailability even after fortification of the cereal flours analyzed, as they all contain an appreciably high amount of these compounds. It has been observed that in addition of 5 or $10 \mathrm{mg}$ of iron (ferric chloride) to a maize meal that contain no enhancers resulted into only about 0.1 $\mathrm{mg}$ increased amount of absorbed iron [29]. In our study, an addition of $5 \mathrm{mg}$ iron fumarate to maize flour resulted into an increase of in vitro iron availability of about $0.086 \mathrm{mg}$ per $100 \mathrm{~g}$ maize flour. Mendoza et al., showed that absorption of iron from unmodified maize (that contain about $12.58 \mu \mathrm{mol}$ phytate), fortified with ferrous sulfate was as low as $1.69 \%$, compared with $1.91 \%$ of a genetically altered low-phytate maize (that contain about $5.59 \mu \mathrm{mol}$ phytate), fortified with ferrous sulfate [26]. In our study, the maize contained $10.8 \mu \mathrm{mol}$ phytate and the in vitro iron availability from the maize fortified with iron fumarate was $1.5 \%$. Table III shows some similarities with the Mendoza et al., study [29]. The in vitro available iron might have also been affected by calcium $[8,30]$ that formed a part of the fortificants, as well as zinc, although zinc oxide has been observed to have no effect on iron absorption in vitro and in human [8, 9, 30.31]. Fiber compounds in the cereal flours might have also negatively affected the in vitro available iron as has been shown [27]. The low amount of ascorbic acid observed in the fortified flour might have contributed to the increase of in vitro available iron observed in some cereal flours, particularly in the fortified maize, finger millet and white sorghum flours [10]. There was no ascorbic acid observed in the unfortified and fortified red sorghum, and this could also account for the low bioavailability of in vitro available iron. Vitamin $A$ and $\beta$ carotene have also been shown to have positive influence on iron absorption though the mode of action is complex and still under debate $[12,13,15,16,29]$.

\section{Total zinc and in vitro available zinc}

The bioavailability of the fortificant zinc added to a particular food is also affected by a number of factors including the dietary constituents such as phytate and polyphenols [30]. In this study, the zinc used was added at a concentration of $5.0 \mathrm{mg} \mathrm{kg}^{-1}$ and the recovery was almost $90 \%$, indicating that there was some loss during handling and addition. However, the bioavailability of zinc was more or less affected in a similar

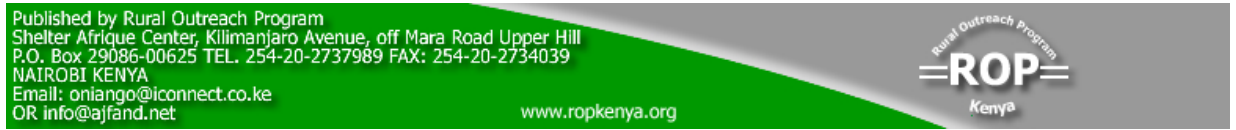


manner to the in vitro available iron. The red sorghum was also shown to have the minimal increase of in vitro available zinc $(1.1 \%)$, compared to finger millet $(7.9 \%)$, white sorghum $(4.8 \%)$ and maize $(5.9 \%)$ flours. The inhibitory effect of phenolics (that were higher in red sorghum) and phytates could have contributed in lowering the bioavailability of the native and added zinc $[9,28]$. It could have also been affected by the addition of iron $[30,31]$. The relative increased bioavailability of zinc in the fortified flours of finger millet, maize and white sorghum, as compared to red sorghum could also have been a result of relatively high amounts of ascorbic acid observed in these flours.

\section{CONCLUSION}

Dietary constituents can be among important determinants of food fortification with micro-nutrients that should be considered when choosing a vehicle for a sustainable and effective food fortification programme. Other sustainable approaches like consumption of fruits and vegetables as part of a daily diet, should be considered as helpful practices that can increase availability of dietary micronutrients. Food pretreatments such as seed germination and fermentation of cereal and legume based foods can also be used to enhance bioavailability of micronutrients. Based on the findings of this study, it is recommended that red sorghum should not be considered a good vehicle for fortifying food with iron and zinc. A combination of enzymic (polyphenol oxidase and phytase) treatment with other processing methods such as soaking, germination and fermentation - that have been shown to enhance degradation of polyphenolic and phytate compounds - can also be used.

\section{Acknowledgements}

We acknowledge the Tanzania Food and Nutrition Centre (TFNC) and United Nations Children's Fund (UNICEF), Dar es Salaam for funding the fortification project. International Programme in the Chemical Sciences (IPICS) of Sweden is acknowledged for funding the analytical work. Nils-Gunnar Carlsson from the Department of Chemistry, Bioscience/Food Science, Chalmers University of Technology, Sweden is thanked for help with HPIC analyses of phytate, iron and zinc. 
Table I. Fortificants, nutrient source and fortification levels

\begin{tabular}{lll} 
Micronutrient & Nutrient source & Fortification Level \\
& & \\
\hline 1. Vitamin A (Retinol) & Vitamin A Palmitate, 250 SD & $2000 \mu \mathrm{gg} / \mathrm{kg}$ \\
$\begin{array}{l}\text { 2. Vitamin } \mathrm{B}_{1} \text { (Thiamine) } \\
\text { 3. Vitamin } \mathrm{B}_{2} \text { (Riboflavin) }\end{array}$ & Thiamin hydrochloride & $1 \mathrm{mg} / \mathrm{kg}$ \\
$\begin{array}{l}\text { 4.Vitamin } \mathrm{B}_{3} \text { (Niacin) } \\
\text { 5. Riboflavin } \quad \text { Vitamin }\end{array}$ & Niacinamide & $1.5 \mathrm{mg} / \mathrm{kg}$ \\
(Cobalamin) & $\mathrm{B}_{12}$ & $15 \mathrm{mg} / \mathrm{kg}$ \\
6. Folate & & $1 \mu \mathrm{g} / \mathrm{kg}$ \\
7. Zinc & Folic acid & \\
8. Iron & Zinc oxide & $300 \mu \mathrm{g} / \mathrm{kg}$ \\
9. Calcium & Ferrous fumarate & $5 \mathrm{mg} / \mathrm{kg}$ \\
10. Ascorbic acid & Calcium carbonate & $15 \mathrm{mg} / \mathrm{kg}$ \\
\hline
\end{tabular}

Table II. Iron binding phenolics and phytate content in different cereal flours. Mean values of duplicate samples $\pm \mathrm{SD}$

\begin{tabular}{lllll}
\hline & $\begin{array}{l}\text { Total phenolics } \\
\mathbf{m g} / \mathbf{1 0 g}\end{array}$ & $\begin{array}{l}\text { Catechols } \\
\mathbf{m g} / \mathbf{1 0 g}\end{array}$ & $\begin{array}{l}\text { Galloyls } \\
\mathbf{m g} / \mathbf{1 0 g}\end{array}$ & $\begin{array}{l}\text { Phytates } \\
\boldsymbol{\mu m o l} / \mathbf{g}\end{array}$ \\
\hline Sorghum udo & $19.4 \pm 0.44 \mathrm{a}$ & $11.7 \pm 0.32 \mathrm{a}$ & $4.0 \pm 0.20 \mathrm{a}$ & $9.6 \pm 1.0 \mathrm{a}$ \\
Finger millet & $3.3 \pm 0.18 \mathrm{~b}$ & $2.0 \pm 0.17 \mathrm{~b}$ & $0.3 \pm 0.09 \mathrm{~b}$ & $10.4 \pm 0.1 \mathrm{a}$ \\
White sorghum & $1.3 \pm 0.04 \mathrm{c}$ & $1.3 \pm 0.10 \mathrm{c}$ & $0.3 \pm 0.07 \mathrm{~b}$ & $12.0 \pm 0.3 \mathrm{~b}$ \\
Maize & $1.6 \pm 0.22 \mathrm{c}$ & $1.1 \pm 0.10 \mathrm{c}$ & $0.5 \pm 0.09 \mathrm{~b}$ & $10.8 \pm 0.8 \mathrm{a}$ \\
\hline
\end{tabular}

Values followed by different letters within the same column differ significant $(\mathrm{p}<0.05)$.

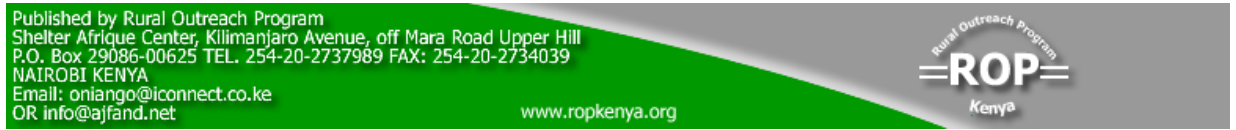




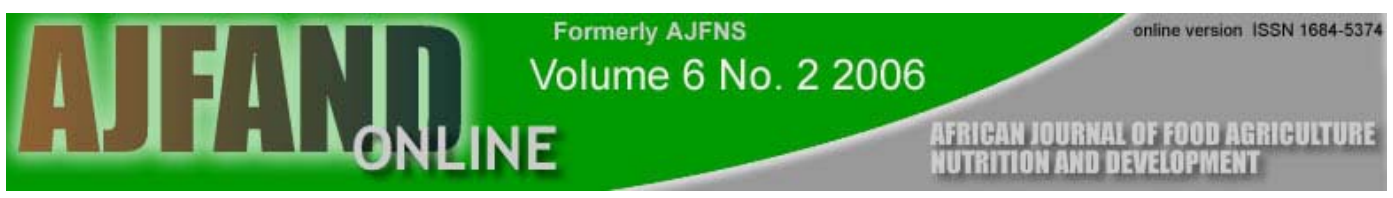

Table III. Iron, zinc and ascorbic acid content and their in vitro availability in unfortified and fortified cereal flours. (Mean values of duplicate samples $\pm \mathrm{SD})$

\begin{tabular}{lccccc}
\hline & $\begin{array}{c}\text { Total iron } \\
\mathbf{m g} / \mathbf{k g}\end{array}$ & $\begin{array}{c}\text { In vitro } \\
\text { available iron } \\
\mathbf{m g} / \mathbf{k g}\end{array}$ & $\begin{array}{c}\text { Total zinc } \\
\mathbf{m g} / \mathbf{k g}\end{array}$ & $\begin{array}{c}\text { In vitro } \\
\text { available zinc } \\
\mathbf{m g} / \mathbf{k g}\end{array}$ & $\begin{array}{c}\text { Ascorbic } \\
\text { acid } \\
\mathbf{m g} / \mathbf{k g}\end{array}$ \\
\hline Unfortified & & & & & \\
Sorghum udo & $51.13 \pm 0.47 \mathrm{a}$ & $1.27 \pm 0.07 \mathrm{a}$ & $22.97 \pm 0.89 \mathrm{a}$ & $0.33 \pm 0.02 \mathrm{a}$ & $\mathrm{ND}$ \\
Finger millet & $31.82 \pm 0.36 \mathrm{~b}$ & $1.46 \pm 0.07 \mathrm{a}$ & $16.86 \pm 0.25 \mathrm{~b}$ & $0.22 \pm 0.01 \mathrm{~b}$ & $\mathrm{ND}$ \\
White sorghum & $51.01 \pm 0.60 \mathrm{a}$ & $0.96 \pm 0.04 \mathrm{~b}$ & $22.16 \pm 0.26 \mathrm{a}$ & $0.20 \pm 0.03 \mathrm{~b}$ & $\mathrm{ND}$ \\
Maize & $35.06 \pm 1.21 \mathrm{~b}$ & $0.63 \pm 0.08 \mathrm{~b}$ & $23.65 \pm 0.52 \mathrm{a}$ & $0.46 \pm 0.05 \mathrm{c}$ & $\mathrm{ND}$ \\
& & & & & \\
Fortified & & & & & \\
Sorghum udo & $62.18 \pm 1.90 \mathrm{c}$ & $1.29 \pm 0.1 \mathrm{a}$ & $27.75 \pm 1.75 \mathrm{c}$ & $0.39 \pm 0.05 \mathrm{c}$ & $4.5 \pm 0.4 \mathrm{a}$ \\
Finger millet & $43.16 \pm 2.45 \mathrm{~d}$ & $1.88 \pm 0.05 \mathrm{c}$ & $21.80 \pm 1.47 \mathrm{a}$ & $0.61 \pm 0.01 \mathrm{~d}$ & $15.8 \pm 2.2 \mathrm{~b}$ \\
White sorghum & $61.67 \pm 0.10 \mathrm{c}$ & $1.93 \pm 0.03 \mathrm{c}$ & $26.23 \pm 0.10 \mathrm{c}$ & $0.40 \pm 0.04 \mathrm{c}$ & $11.1 \pm 0.4 \mathrm{c}$ \\
Maize & $43.67 \pm 0.61 \mathrm{~d}$ & $1.48 \pm 0.04 \mathrm{a}$ & $27.87 \pm 1.59 \mathrm{c}$ & $0.71 \pm 0.06 \mathrm{e}$ & $29.6 \pm 0.7 \mathrm{~d}$ \\
\hline
\end{tabular}

Values followed by different letters within the same column differ significant $(\mathrm{p}<0.05)$.

ND: Not detected by the method used.

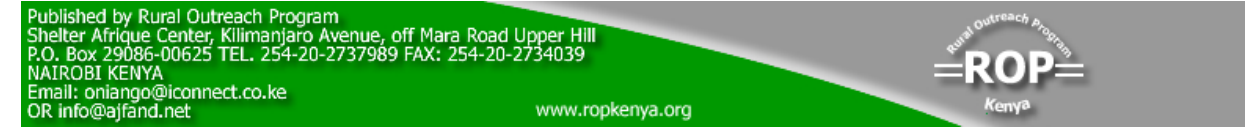




\section{REFERENCES}

1. Stoltzfus R Defining iron-deficiency anaemia in public health terms: A time for reflection. J. Nutr. 2001; 131 (Suppl.): 565-567.

2. Tatala SR, U Svanberg and B Mduma Low dietary iron bioavailability is a major cause of anaemia: A nutritional survey in Lindi District of Tanzania. Am. J. Clin. Nutr. 1998; 68: 171-178.

3. Hurrell RF Fortification: Overcoming technical and practical barriers (Review). J. Nutr. 2002; 132: 806s-812s.

4. Matuschek E, E Towo and U Svanberg Oxidation of polyphenols in phytatereduced high-tannin cereals: Effect on different phenolic groups and on in vitro available iron. J. Agric. Food Chem. 2001; 49: 5630-5638.

5. Towo E, U Svanberg and GD Ndossi Effect of grain pre-treatment on different extractable phenolic groups in cereals and legumes commonly consumed in Tanzania. J. Sci. Food Agric. 2003; 83: 980-986.

6. Towo E, U Svanberg and A Kamala Phenolic compounds, phytate, citric acid and the in vitro iron accessibility of cowpeas, mung beans and four varieties of kidney beans. Afric. J. Food Agric. Nutr. and Dev. 2003; 3: 53-59.

7. Lönnerdal B Dietary factors influencing zinc absorption. J. Nutr. 2000; 130: 1378S-1383S.

8. Hullberg L, M Brune, M Erlandsson AS Sandberg and HL Rossander Calcium: Effect of different amounts on non-heme and heme-iron absorption in humans. Am. J. Clin. Nutr. 1991; 53: 112-119.

9. Romaňa DL, B Lönnerdal and KH Brown Absorption of zinc from wheat products fortified with iron and either zinc sulfate or zinc oxide. Am. J. Clin. Nutr. 2003; 78: 279-283.

10. Davidsson L, T Walczyk, A Morris and RF Hurrel Influence of ascorbic acid on iron absorption from an iron-fortified, chocolate-flavored milk drink in Jamaican Children. Am. J. Clin. Nutr. 1998; 67: 873-877.

11. Lee SK and AA Kader Preharvest and postharvest factors influencing vitamin C content of horticultural crops. Posthar. Biol. Techn. 2000; 20: 207-220

12. Layrisse M, M Garcia-Casal, L Solano, M Baron, F Arguello, D Llovera, J Ramirez, I Leets and E Tropper New property of vitamin A and B-carotene on human iron absorption: Effect on phytate and polyphenols as inhibitors of iron absorption. Archivos Latinamericanos de Nutr. 2000; 50: 243-248.

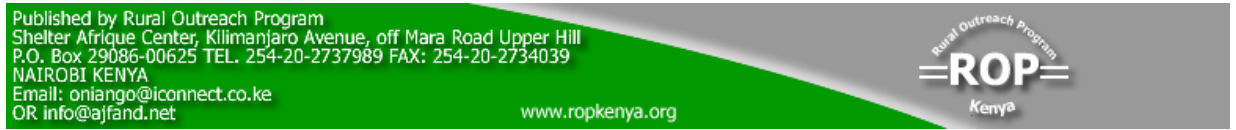


13. Garcia-Casal M, M Layrisse, JP Pen a-Rosasb, J Ramý'a-reza, I Leetsa and P Matusa Iron absorption from elemental iron-fortified corn flakes in human. Role of vitamin A and C. Nutrition Research 2003; 23: 451-463.

14. Garcia-Casal M, M Layrisse, L Solano, M Baron, F Arguello, D Llovera, J Ramirez, I Leets and E Tropper Vitamin A and beta carotene can improve nonheme iron absorption from rice, wheat and corn by humans. Europ . J. Nutr. 1998; 128: 646-650.

15. Garcia-Casal M, I Leets and M Layrisse B-Carotene and inhibitors of iron absorption modify iron uptake by Caco-2 cells. J. Nutr. 2000; 130: 5-9.

16. Walczyk T, L Davidsson, L Rossander-Hulthen, L Hallberg and RF Hurrell No enhancing effect of vitamin A on iron absorption in human. Am. J. Clin. Nutr. 2003; 77: 144-149.

17. Sapers GM Determination of ascorbic acid, dehydro-ascorbic acid and ascorbic acid-2-phosphate in infiltrated apple and potato tissue by HPLC. J. Chromatogr. 1990; 503: 431-436.

18. Price ML and LG Butler Rapid visual estimation and spectrophotometric determination of tannin content of sorghum grain. J. Agric. Food Chem. 1977; 25: $1268-1273$.

19. Brune M, L Hallberg and AB Skanberg Determination of iron-binding phenolic groups in foods. J. Food Sci. 1991; 56: 128-131,167.

20. Carlsson NG, EL Bergman, E Skoglund, K Hasselblad and AS Sandberg Rapid analysis of inositol phosphates. J. Agric. Food Chem. 2001; 49: 16951701 .

21. Fredrickson M, NG Carlssnon, A Almgren and AS Sandberg Simultaneous and sensitive analysis of $\mathrm{Cu}, \mathrm{Ni}, \mathrm{Zn}, \mathrm{Co}, \mathrm{Mn}$ and $\mathrm{Fe}$ in Food and biological samples by iron chromatography. J. Agric. Food Chem. 2002; 50: 59-65.

22. Svanberg $\mathbf{U}, \mathbf{W}$ Lorri and AS Sandberg Lactic fermentation of non-tannin and high-tannin cereals: Effects on in vitro estimation of iron availability and phytate hydrolysis. J. Food Sci. 1993; 58: 408-412.

23. Glahn RP, C Lai, J Hsu, JF Thompson, M Quo and DR Van-Campen Decreased citrate improves iron availability from infant formula: Application of an in vitro digestion-Caca-2 cell culture model. J. Nutr. 1998; 128: 257-264.

24. Elless MP, MJ Blaylock, JW Huang and CD Gussman Plant as a natural source of concentrated mineral nutritional supplements. Food Chem. 200; 71: $181-188$.

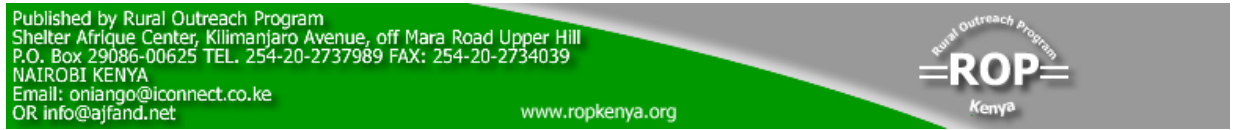


25. Manglano P, R Farre, MJ Lagarda, P Abellan, F Romero and G Clemente Stability of ascorbic acid in adapted milk-based infant formulae during storage. $J$. Sci. Food Agric. 2004; 84: 1126-1130.

26. Mendoza C FE, Viteri,B Lönnerdal, V Raboy, KA Young and KH Brown Absorption of iron from unmodified maize and genetically altered low-phytate maize fortified with ferrous sulfate or sodium iron EDTA. Am. J. Clin. Nutr. 2001; 73: 80-85.

27. Hurrell RF Influence of vegetable protein sources on trace elements and mineral bioavailaility. J. Nutr. 2003; 133: 2973s-2977s.

28. Champague ET and BQ Phyllippy Effect of $\mathrm{pH}$ on calcium, zinc and phytate solubilities and complexes following in vitro digestion of soy protein isolates. $J$. Food Sci. 1989; 54: 578 - 592.

29. Layrisse M, C Martinez-Torres and M Gonzalez Measurement of the total daily iron absorption by the extrinsic tag model. Am. J. Clin. Nutr. 1974; 27: 152162.

30. Lynch SR Interaction of iron with other nutrients. Nutr. Reviews, 1997; 55: 102110.

31. Herman S, IJ Griffin, S Suwart, F Ernawati, D Permaesih, D Pambudi and SA Abrahams Co-fortification of iron-fortified flour with zinc sulfate, but not zinc oxide decreases iron absorption in Indonesian Children. Am. J. Clin. Nutr. 2002; 76: 813-817.

32. Wilkinson L SYSTAT: The system for statistics, IL SYSTAT Inc, Evanston IL Press. 1990

33. Rubin SH, A Emodi and L Scalpi Micronutrient addition to cereal grain products. Cereal Chem. 1977; 54: 895-903. 